\title{
超音波とマイクロバブルによる セラノスティクス
}

\section{小俣大樹”・鈴木～亮”・ Johan Unga* • 丸山一雄”}

Theranostics based on microbubbles and ultrasound

Ultrasound imaging and ultrasound therapy using high intensity focused ultrasound are applied in clinic. Ultrasound is a promising candidate for developing theranostics system because of its safety, non-invasiveness, relatively cheap equipment and imaging in real time. Ultrasound contrast agents (Microbubble) have been developed to visualize tissues clearly. Recently, the combination of microbubbles and ultrasound is not only applied for imaging but also therapy like enhanced drug delivery. Ultrasound can induce microbubble oscillation, stable cavitation and inertial cavitation depending on the ultrasound intensity. These phenomena are used for imaging and therapy. Although several microbubbles have been developed in the world and applied for ultrasound diagnostics, it is not approved for therapy. Therefore, in order to establish ultrasound theranostics, we have tried to develop novel bubbles which are suitable for diagnostics and therapeutics. In this review, we describe our studies and introduce recent studies for establishing ultrasound theranostics.

超音波は臨床において診断と治療に利用されているため、セラノスティクスを実現していくうえで 有用な物理エネルギーであると期待されている。現在、数種の超音波造影剂(マイクロバブル)が臨床 で超音波診断のために使用されている。最近では、超音波を照射することで生じるマイクロバブルの 振動や圧壊といつた振る舞いを利用した薬物デリバリー法の開発など治療への応用が研究されてい る。しかしながら、現在臨床で使用されているマイクロバブルは超音波診断を目的として開発されて おり、治療を目的としたマイクロバブルは承認されていない。そこで筆者らは新規バブルの開発を行 い超音波セラノスティクスの研究を進めてきた。本稿では、これまでの筆者らの取り組みとともに、 最近の超音波セラノスティクスの研究動向について紹介する。

Daiki Omata*, Ryo Suzuki , Johan Unga*, Kazuo Maruyama*

Keywords: Ultrasound, Microbubble, Theranostics

1. はじめに

セラノスティクス(Theranositcs) は、治療 (Therapeutics) と診断(Diagnostics)を組み合わせ た造語であり、Funkhouser John が最初に提唱し たとされている1)。セラノスティクスは治療と診断 を一体的に行うシステムを指し、治療機能と診断 機能をもつデバイスを使用することや、治療の最 適化のための診断を意味している。例として、ゼ ヴァリン®(イブリツモマブ チウキセタン)やハー

\footnotetext{
* Faculty of Pharma Sciences, Teikyo University
}

セプチン ${ }^{\circledR}($ トスツズマブ)があげられる。ゼヴァ リン ${ }^{\circledR}$ は CD20陽性の B 細胞性腫瘍を標的として おり、治療の適格性を確認するためにインジウム $\left({ }^{111} \mathrm{In}\right)$ 標識イブリツモマブ チウキセタンを投与 後、シンチグラムを撮像し、骨髄への取り达みなど の治療リスクを評価する。適格性が確認された場合 には、イットリウム $\left({ }^{90} \mathrm{Y}\right)$ 標識イブリッモマブ チ ウキセタンを使用した放射線治療を行う。治療の最 適化のための診断と実際の治療が可能なセラノス ティクスといえる。現在利用される診断方法として、 MRI、PET、CT、蛍光、超音波などがあげられる。 そのなかで超音波は古くから超音波造影診断に使用 
され、近年の超音波技術の進展に伴い $3 \mathrm{D}$ 造影が可 能になり、超解像超音波についても研究が進められ ている2）ささらに、強力集束超音波を用いて超音波 エネルギーを数 $\mathrm{mm}^{3}$ の範囲に集め、腫瘍組織を焼 灼する治療も行われている。このように超音波は診 断と治療に利用される物理エネルギーであるととも に、超音波造影装置は比較的小型で安価であること、 被曝がないため繰り返し利用可能であること、リア ルタイムイメージングが可能であることなどの利点 がある。そこで筆者らは超音波に注目したセラノス ティクス構築に取り組んでいる。本稿では、超音波 セラノスティクスについて、筆者らの研究をまじえ、 最近の研究動向を紹介する。

\section{2. 超音波と超音波造影剂(マイクロバブル)}

胎児超音波検査で使用するような超音波のみに よる画像検査が可能であるが、超音波造影剂(マイ クロバブル）を使用する画像検査も行われる。マイ クロバブルは名前のとおり 1 10 $\mu \mathrm{m}$ 程度のサイズ をもち、気体を脂質などで覆い安定化した気泡で ある(図1)。マイクロバブルを使用した超音波造影 は1960年代後半に初めて行われた。生理食塩水を 擋汼した溶液を投与することで超音波エコーが増強 したことが始まりである。これは、撹拌により圧縮 された気泡が超音波を反射し、超音波シグナルを増 強したことによる。1990年代になると空気をアル ブミンで覆ったマイクロバブルがFDAに認可され
た。その後、マイクロバブルの安定性と生体適合性 の改善が行われ、現在ではパーフルオロカーボンや 六フッ化硫黄を脂質で覆ったマイクロバブルが日米 欧で認可されている(表)。

超音波診断にはさまざまな超音波造影法が利用で きる。一般的な超音波造影法であるブライトネス モード(B モード)は、超音波の反射を利用した方法 であり、組織間で音響インピーダンスが異なるため に起こる超音波の反射波を画像化している。マイク ロバブルを使用した場合には、超音波がマイクロバ ブルにあたることで生じる反射波を画像化できる が、同様に組織からの反射波も含んだ信号を画像化 することになる。コントラストモードは、マイクロ バブルの振動を利用した造影方法である。マイクロ バブルに対して超音波を照射するとマイクロバブル は振動し、その振動により反射波には照射した超音 波よりも高い周波数の超音波(高調波成分)が含まれ る。位相を反転した 2 回のパルス波を加算すること で、組織からの信号を低減し、マイクロバブルの反 射波に含まれる高調波成分の信号を強調して画像化 することが可能である。第一世代のマイクロバブ ルであるレボビスト ${ }^{\circledR}$ は、超音波照射により気泡が 崩壊することで生じるハーモニック信号 (高調波成 分)を画像化するものであり、心エコー図検査、ド プラ検査、子宮卵管エコー図検査に使用された。こ の造影ではマイクロバブルを破壊しながら診断する ため、撮像する夕イミングに工夫が必要であった。 第二世代としてパーフルオロカーボンや六フッ化硫

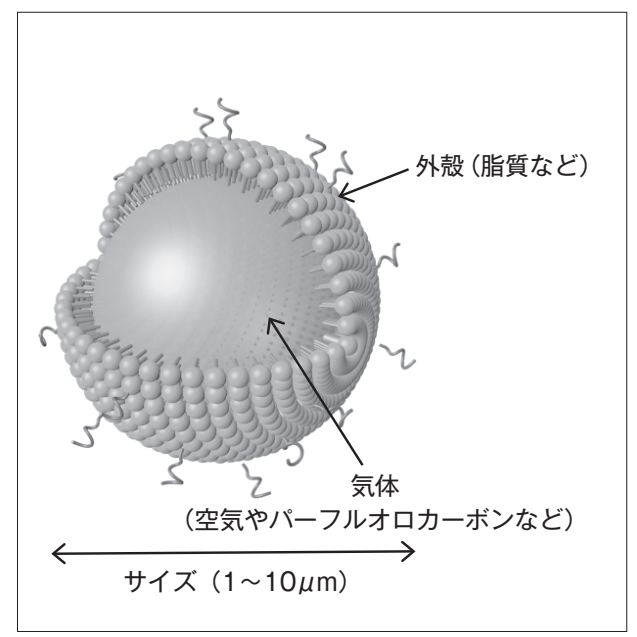

表 上市されたマイクロバブル

\begin{tabular}{|c|c|c|c|c|}
\hline マイクロバブル & ガ ス & 外殼成分 & $\begin{array}{c}\text { 粒子サイズ } \\
(\mu \mathrm{m})\end{array}$ & $\begin{array}{l}\text { 個数濃度 } \\
\text { (個 } / \mathrm{mL})\end{array}$ \\
\hline レボビスト & 空気 & $\begin{array}{l}\text { ガラクトース、 } \\
\text { パルミチン酸 }\end{array}$ & $1 \sim 3$ & \\
\hline オプチゾン & $\begin{array}{l}\text { パーフルオロプロパン } \\
\left(\mathrm{C}_{3} \mathrm{~F}_{8}\right)\end{array}$ & 血清アルブミン & $2.5 \sim 4.5$ & $5 \sim 8 \times 10^{8}$ \\
\hline デフィニティー & $\begin{array}{l}\text { パーフルオロプロパン } \\
\left(\mathrm{C}_{3} \mathrm{~F}_{8}\right)\end{array}$ & $\begin{array}{l}\text { DPPC、DPPA、 } \\
\text { MPEG5000DPPE }\end{array}$ & $1.1 \sim 2.5$ & $\begin{array}{c}6.4 \times 10^{7} \\
\sim 1.2 \times 10^{10}\end{array}$ \\
\hline ソノビュー & $\begin{array}{l}\text { 六フッ化硫黄 } \\
\left(\mathrm{SF}_{6}\right)\end{array}$ & $\begin{array}{c}\text { DSPS、DSPG、 } \\
\text { パルミチン酸 }\end{array}$ & $1.5 \sim 2.5$ & $1.5 \sim 5.6 \times 10^{8}$ \\
\hline ソナゾィド & $\begin{array}{l}\text { パーフルオロブタン } \\
\left(\mathrm{C}_{4} \mathrm{~F}_{10}\right)\end{array}$ & HSPS & $2 \sim 3$ & $9.1 \times 10^{8}$ \\
\hline
\end{tabular}

図1 マイクロバブルの構造 
黄をタンパク質や脂質でコーティングしたマイクロ バブルが開発された。本邦では、パーフルオロブタ ンを水素添加卵黄ホスファチジルセリンナトリウム で覆った構造を有するソナゾイド®が承認されてい る。肝腫瘤性病変と乳房腫瘤性病変の診断に使用さ れ、肝腫瘤性病変の造影では、投与直後から得られ る血管イメージングとクッパーイメージングが用い られる。ソナゾイド®の外殼成分はホスファチジル セリンであるため、ホスファチジルセリンに対する レセプターを有する肝臓のクッパー細胞に取り込ま れる。そのため血管の造影だけでなく、クッパー細 胞の存在する正常肝実質を造影可能であり、クッ パー細胞の存在しない悪性腫瘍を陰影欠損像として 診断することができる。

近年、マイクロバブルと超音波を使用した治療へ の応用についても多くの研究が進められている。比 較的低強度の超音波とマイクロバブルを利用したソ ノポレーション法は薬物や遺伝子デリバリー法とし て期待されている。マイクロバブルは照射される超 音波の強度によりその振る舞いが変化する(図2)。 超音波は疎密波であるため、正圧と負圧の異なる音 圧からなる波であり、超音波の正圧により気泡(マ イクロバブル）は収縮し、負圧により膨張する。前
述したように、超音波診断に使用される低強度の超 音波照射において、マイクロバブルは超音波を反 射し B モードの超音波造影像として画像化される。 または、マイクロバブルの収縮澎張による振動から 生じる高調波成分を画像化し、コントラストモード の超音波造影像として画像化できる。高い強度の超 音波照射により、気泡は収縮と澎張を繰り返し大き くなっていき、内圧が外圧に耐えられなくなると気 泡の圧壊が起こる。マイクロバブルの超音波反射や 振動は超音波造影に利用される。マイクロバブルの 振動や圧壊に伴う機械的作用はソノポレーション法 として薬物や遺伝子デリバリーへの応用が研究され ている。圧壊に伴う熱的作用はがん温熱療法への応 用が期待されている。マイクロバブルと超音波によ る薬物デリバリーについて、詳細なメカニズムは明 らかとなっていないが、超音波照射によってマイク ロバブルの振動掞よび圧壊に伴うマイクロジェット 流の誘導が起こり、この機械的作用によって細胞膜 に一過性の小孔が生じると考えられている3)。小孔 の形成により細胞膜の透過性が一時的に高まり、薬 物の細胞質へのデリバリー効率が高まると考えられ る(図3)。超音波照射によるマイクロバブルのさま ざまな振る舞いに伴う、機械的作用、熱的作用を利

\section{超音波（疎密波）}
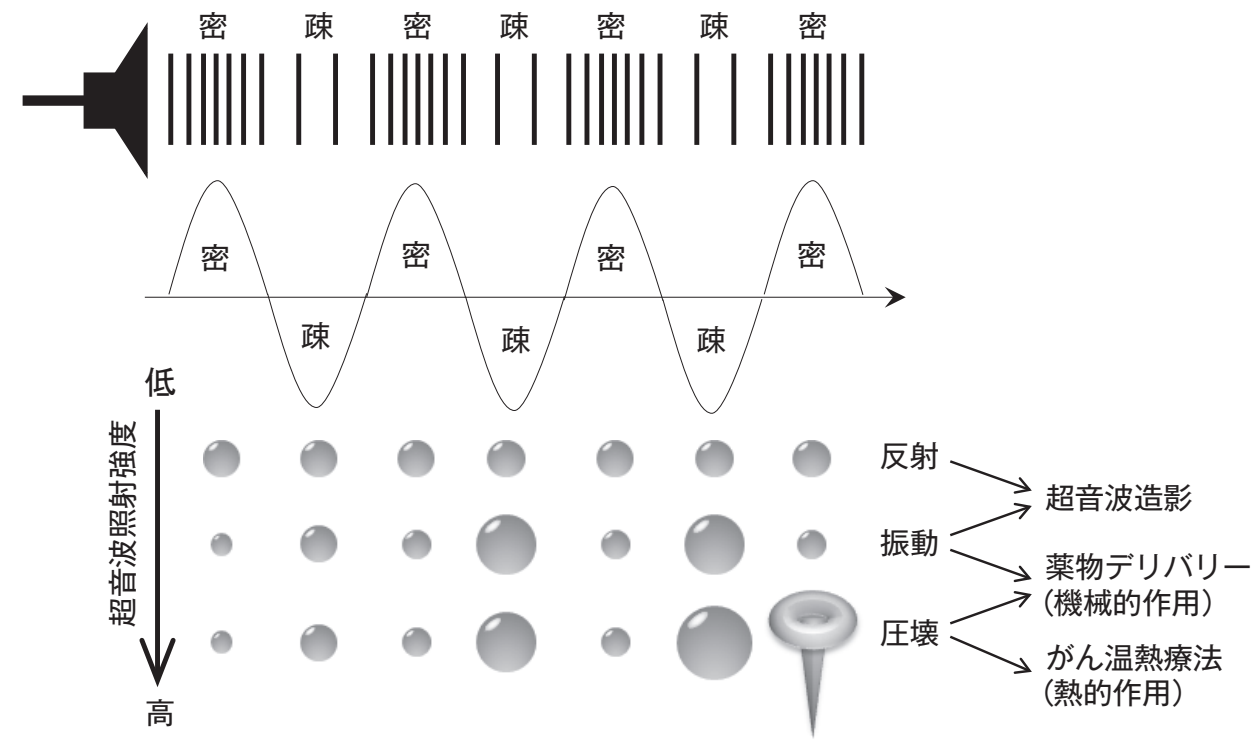

図2 マイクロバブルの振る舞い

マイクロバブルの異なる振る舞いが超音波造影や治療に利用される。 


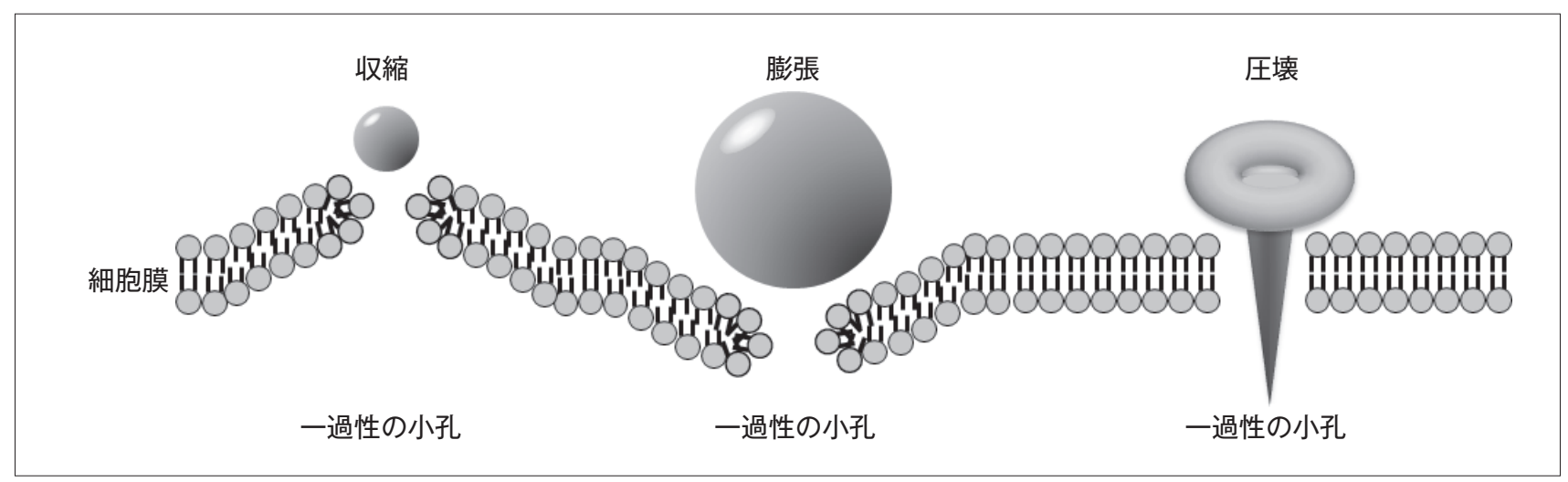

図3 ソノポレーション法

用した疾患治療について研究が進められている。

現在上市されているマイクロバブルは超音波診断 を目的としている。そのため超音波セラノスティク スを構築していくなかで治療を考えた場合に、既存 のマイクロバブルが治療のために最適であるかは定 かではない。マイクロバブルの生体内での安定性や 超音波に対する応答性は、内包する気体、外殼成分、 粒子サイズなどにより影響を受ける ${ }^{4)}$ 。そこで筆者 らは、診断と治療を目的とした超音波セラノスティ クスを構築するため新規バブルの開発を進め、超音 波造影や薬物デリバリーについて評価してきた。

\section{3. 超音波とマイクロバブルによるイメージング}

さまざまなマイクロバブルが開発されるなかで、 超音波診断法においてもマイクロバブルを用いた 超音波造影に特有な方法が開発されてきた。Flash Replenishment Imaging(FRI) は、超音波造影を行 い撮像中に存在するマイクロバブルをフラッシュエ コー(高音圧の超音波)を使用して崩壊させること で、血管内を再灌流するマイクロバブルを観察し、 リアルタイムに血流動態を観察する方法である。ほ かにも Maximum Intensity Projection(MIP)法は、 マイクロバブル由来の輝度のなかで最高輝度のみを 画像化してくことで、微細な血管構造を描出するこ とを可能にしている。

腫瘍の血管構造や血流動態を観察することは、治 療効果の予測や評価のために有用であると考えられ る。そこで、開発してきたバブルを用いた腫瘍血管 の造影を行い、さらにマイクロバブルを用いた特有

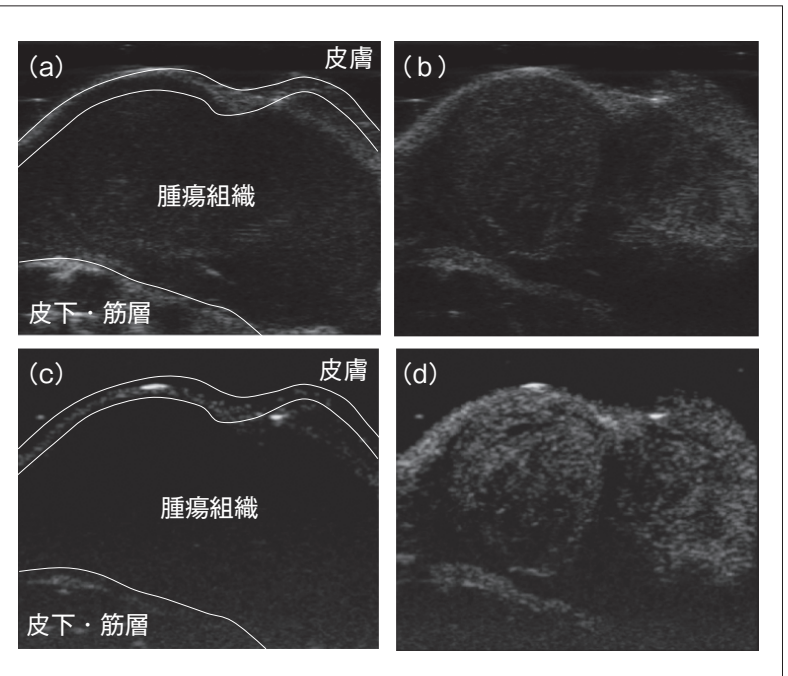

図4 バブルと超音波による腫瘍組織の造影

(a) B モード画像バブル投与前。(b) B モード画像バブル投与後。 (c)コントラストモード画像 バブル投与前。

(d) コントラストモード画像 バブル投与後。

な超音波造影方法に適応可能か検討を加えた。マウ スメラノーマ細胞であるB16/BL6 細胞を移植した 担がんマウスに対して、バブルを尾静脈内より投与 し、直ちに腫瘍組織の超音波造影を行った。超音 波造影装置はVEVO2100、周波数は18 MHz を使 用した。一般的に使用される超音波造影法である B モードとマイクロバブルの造影に汎用されるコント ラストモードにおいて、腫瘍組織のバブルを観察し た。その結果、B モードおよびコントラストモード いずれにおいてもバブルを投与することで、腫瘍内 の血管様構造を観察することができた(図4)。今回 の観察ではバブル投与直後から腫瘍組織の超音波造 影を行っているため、バブルは血管内に存在してい ると推察された。腫瘍の血管様構造が観察できたこ 
とから、尾静脈から投与したバブルが、全身を循環 し腫瘍組織まで流入したことになる。同様に、マイ クロバブルに特有な超音波造影法である FRI に開 発したバブルが利用可能か評価した。その結果、フ ラッシュエコーを照射することでバブル由来の輝度 が消失し、再灌流するバブルの様子を観察すること が可能であった。超音波造影の画像から得られる輝 度を解析した結果からも、フラッシュエコーによる 輝度の低下とバブルの再灌流に伴う輝度の再上昇を 確認した。また、MIP法によるバブルの観察を行っ たところ、腫瘍組織における微小な血管構造の描出 が可能であった。これらのことから、開発してきた バブルは FRIや MIP といった方法により腫瘍血管 の血流動態や微小血管構造を評価できることが示唆 された。マイクロバブルと超音波を利用した超音波 造影は本邦ではすでに肝腫瘤性病変の診断に使用さ れているが、現在もさまざまな研究が進められてお り対象疾患が拡大することが期待される。ソナゾイ

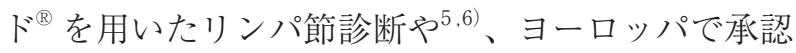
されているソノビュー ${ }^{\circledR}$ を用いたクローン病に対す る超音波診断が報告されている7)。

最近では、より正確に微細な血管構造を描出する ための超解像超音波に関する研究が注目を集めて いる ${ }^{2,8,9)}$ 。これは、個々のマイクロバブルの血管内 の動きを高いフレームレートで撮像し、マイクロバ ブルの動きを追跡することで正確に血管構造を画 像化する手法である。Opacic らは、この手法を用 いヒトの腫瘍の微小血管構造を描出可能であること を報告している ${ }^{2)}$ 。微小血管構造を把握できるよう になることから、腫瘍の状態を把握するための診断 や治療効果の判定などに有用であるとともに、ほか の炎症性疾患やリウマチなどの免疫疾患の診断など にも役立つ技術になると考察していた。また、分子 標的型マイクロバブルによる腫瘍や循環器疾患にお ける血管内皮のイメージングが盛んに研究されてい る。腫瘍血管の造影では VEGFR2を標的としたマ イクロバブルを用いることで、腫瘍の新生血管を造 影できることが報告され、BR55というマイクロバ ブルは乳がんや前立腺がん患者などで評価されてい $3^{10,11)}$ 。筆者らは腫瘍血管に高発現するシンデカン を標的とした AG73ペプチド修飾バブルを開発し、
腫瘍血管造影が可能であることを報告している ${ }^{12)}$ 。 また、ほかのグループからは、 $\alpha \mathrm{v} \beta 3$ インテグリン と VEGFR2を標的としたマイクロバブルが報告さ れている ${ }^{13)}$ 。血栓の診断のために標的分子を修飾し たマイクロバブルも研究されている ${ }^{14,15)}$ 。超解像超 音波や分子標的型のマイクロバブルを利用すること で、より正確に疾患の病態を把握し、治療の計画を 立て、治療効果を評価するということが可能になる と期待される。

\section{4. 超音波とマイクロバブルによる治療}

高強度の超音波エネルギーを数 $\mathrm{mm}$ 単位で患部に 対して正確に照射することのできる強力集束超音波 が臨床応用され、超音波エネルギーによる前立腺が んや子宮筋腫の低侵襲的焼灼治療が行われている。 脳疾患治療への超音波エネルギーの利用も進めら れ、本態性振戦の治療を目的とした脳に対する超音 波照射装置が治療用医療機器 (ExAblate4000) とし て2016年に薬事承認を得ている。このように超音 波は治療にも利用できる物理エネルギーとして注目 されている。さらに最近では、超音波とマイクロバ ブルを併用することで、細胞内や組織に対して薬物 を効率よく送達するための超音波技術が研究されて いる。筆者らは超音波セラノスティクスの実現のた めに新規バブルの開発を進め、前述したようにバブ ルの超音波造影能を評価するとともに、バブルを用 いた薬物デリバリーや疾患治療についても取り組ん できたので紹介する。

マイクロバブルと超音波による細胞膜透過性や組 織透過性の无進による薬物送達効率の向上が期待で きる。まず、簡便に観察可能なマウスの耳において、 モデル薬物として青色色素であるエバンスブルーを 用い、バブルと超音波による血管透過性元進につい て検討した(図5)。エバンスブルーとバブルをマウ ス尾静脈から投与し、超音波造影用のゲル上にのせ たマウスの右耳に超音波を照射した。今回使用した 超音波は非集束型の超音波である。超音波照射 10 分後、1時間後にマウスの左右の耳を観察したとこ ろ、超音波を照射した右耳のみにおいてエバンスブ ルーが血管外へ漏出している様子が観察できた。ま 
た、10分後よりも1時間後においてよりエバンスブ ルーが漏出していることを確認した。このことから、 バブルと超音波を利用することで血管の透過性を充 進可能であり、今回の条件では 1 時間程度透過性の 充進効果が持続することが示唆された。次に、バブ ルと超音波を用いた腫瘍組織への薬物送達効率の向 上および抗腫瘍効果について検討を行った ${ }^{16)}$ 。担が んマウスにドキソルビシンとバブルを静脈内投与 し、経皮的に腫瘍組織に向けて超音波を照射した。 ドキソルビシン単独投与 $(1 \mathrm{mg} / \mathrm{kg})$ と比べて、ドキ ソルビシン $(1 \mathrm{mg} / \mathrm{kg})$ とバブルを投与し超音波を併 用した群では高い腫瘍増殖抑制効果が観察された。 この効果は $5 \mathrm{mg} / \mathrm{kg}$ のドキソルビシン単独処置群 と同程度であった。また、腫瘍組織へのドキソルビ シン移行量を測定したところ、ドキソルビシン単独 投与群と比べて、ドキソルビシンとバブルを投与し 超音波を併用した群で、腫瘍組織内のドキソルビシ ン移行量の増大が確認された。バブルと超音波を併 用することで、腫瘍血管の透過性が充進し、ドキソ ルビシンの腫瘍組織内への移行量が増加した結果、 高い腫瘍増殖効果が得られたと考えられた。現在、 鳥取大学の大崎先生との共同研究において、イヌの がんに拉けるバブルと超音波による薬物送達効率の 向上について検討を進めている。このようにバブル と超音波の併用は薬物送達効率を向上し、より優れ たがん治療法になる可能性がある。実際に、ノル
ウェーのグループはヒト膵蔵がん患者に対してマイ クロバブルと超音波によりゲムシタビン治療効果の 増強を試みる世界初の臨床試験を行っている ${ }^{17)}$ 。膵 臓がんに対する化学療法の治療効果は十分とはいえ ず、Dimcevski らは診断用の超音波とヨーロッパで 承認されているソノビュー ${ }^{\circledR} を$ 使用したゲムシタビ ンの治療効果増強を目指した第I相試験を行った。 10 人の切除不能膵臓がん患者に対して、本治療を 行ったところ、5名の患者で腫瘍の縮小が認められ た。また、いずれの患者においても特別な毒性や副 作用は観察されなかった。ゲムシタビン単独で治療 した患者と比べて、併用治療を行った患者で治療サ イクル数を増やすことが可能であった。この治験は 第I相試験であったため、患者数を増やした評価を していく必要があるが、この結果は超音波とマイク ロバブル、化学療法の併用は有用ながん治療方法に なると期待させるものである。

がん治療のための腫瘍組織への薬物送達以外にも 脳への薬物送達のためにマイクロバブルと超音波を 利用した技術が注目を集めている。脳への薬物送達 では、血液と脳実質の間の物質移動を厳密に制御す る血液脳関門 (Blood brain barrier：BBB)が存在す るため、脂溶性の低分子薬物以外は脳へ送達するこ とが困難である。これが脳疾患治療のための医薬品 開発の $1 つ の$ 問題となり、BBB の薬物透過性を制御 するためにさまざまな方法が研究されている。その なかで、マイクロバブルへの超音波 照射で生じる振動や圧壊といった振 る舞いを利用して、一時的に BBB をオープニングし脳内へ薬物を送達 する方法が近年注目されている。筆 者らが開発してきたバブルと超音波 による BBB オープニングについて、 モデル薬物としてエバンスブルーを 使用して検討した。その結果、バブ ルと超音波を併用することで超音波 を照射した位置選択的にエバンスブ ルーが移行することを確認した。さ らに、周波数や超音波強度を最適化 することで、組織傷害性を抑えられ ることを見出してきた。これらの結

図5 バブルと超音波による血管透過性え進 
果から、バブルと超音波を用いることで低侵襲的 にBBB オープニングが可能になることが示唆され た。この分野ではカナダの Sunnybrook Research Institute のグループが精力的に研究開発を進めて いる。2015年に脳腫瘍患者に対して抗がん剂を効 率的にデリバリーするために、マイクロバブルと集 束超音波を使用した臨床試験を行った ${ }^{18)}$ 。2017年 にはアルツハイマー病の患者に対する集束超音波を 使用したBBB オープニングの第I相試験が始まっ た ${ }^{19)}$ 。このように超音波とマイクロバブルを利用し た脳疾患に対する治療が劇的に進展しようとしてい る。

マイクロバブルと超音波による機械的作用を利用 した薬物デリバリーのみではなく、熱的作用を利用 した治療法も研究されている。筆者らは、マイクロ バブルと超音波の熱的作用を利用したがん温熱療法 について報告してきた20)。正常細胞に比べて、がん 細胞は熱に対して抵抗性が低いため、43度の温度 で死滅する。そこでまず、十分な温度上昇が得られ るか検討するため、担がんマウスの腫瘍組織内にバ ブルを投与し、超音波を照射し腫瘍組織の温度を測 定した。その結果、超音波のみを照射した群では約 38 度であったの対して、バブルと超音波を併用し た群では約 44 度まで上昇することを確認した。次 に、抗腫瘍効果について検討したところ、超音波の みを照射した群と比較し、バブルと超音波を併用し た群において有意な腫瘍増殖抑制効果が確認でき た。バブルと超音波の熱的作用を利用することで、 腫瘍組織の温度を上昇させることが可能であり、が ん温熱療法への応用が期待される。

\section{文献}

1) Kelkar S.S. and Reineke T.M., Bioconjug. Chem., 22, 18791903 (2011)

2) Opacic T., et al., Nat. Commun., 9, 1527 (2018)

3) Fan Z., et al., Ther. Deliv., 5, 467-486 (2014)

4) Sirsi S. and Morden M., Bubble Sci. Eng. Technol., 1, 3-17 (2009)

5) Shiamazu K., et al., Cancer Med., 6, 1915-1922 (2017)

6) Oikawa S.I., et al., Oncol. Lett., 15, 4171-4176 (2018)

7) Quaia E., et al., Radiolgy, 281,606-616 (2016)

8) Harput S., et al., IEEE Trans. Ultrason. Ferroelectlr. Freq. Control., 65, 803-814 (2018)

9) Song P., et al., IEEE Trans. Ultrason. Ferroelectlr. Freq. Control., 65, 149-167 (2018)

\section{5. おわりに}

超音波はすでに診断と治療に利用され、セラノス ティクスを実現していくために有望な物理エネル ギーであると考えられる。超音波技術の発展によ り $3 \mathrm{D}$ 造影やマイクロバブルを利用した超解像超音 波造影の開発が進められ、造影画像の高解像度化お よび定量的な解析が可能になりつつある。このよう な技術は超音波診断可能な疾患を増やし、また、術 者の技量に依存する側面があった超音波造影法をよ り再現性の高い方法にすると考えられる。治療にお いては強力集束超音波やソノポレーション法による がん治療や脳疾患治療のための臨床試験が進めら れている。VEGFR2を標的にしたマイクロバブル (BR55)のヒトでの臨床試験が進められているが、 BR55は診断を目的にしたものであり、治療におい ては安全に高い効果が得られるように組成やサイズ などを最適化したマイクロバブルの開発が重要であ ると考えている。超音波セラノスティクスを実現し ていくためには、医学、薬学、工学などさまざまな 分野が融合し開発に取り組む必要がある。筆者らも 超音波セラノスティクスが医療に貢献するよう研究 に取り組んでいきたい。

\section{謝辞}

紹介した研究の一部は、文部科学省私立大学戦略的基盤 形成事業(平成 25 年 29 年度) およびAMED脳科学研究戦 略推進プロジェクト(課題番号JP16 dm0107115)によるも のである。

10) Willmann J.K., et al., J. Clin. Oncol., 35, 2133-2140 (2017)

11) Smeenge M., et al., Invest. Radiol., 52, 419-427 (2017)

12) Negish Y., et al., Biomaterials., 34, 501-507 (2013)

13) Yuan H.X., et al., Ultrasound Med. Biol., 44,1460-1467 (2018)

14) Gunther F., et al., Sci. Rep., 7, 14898 (2017)

15) Lux J., et al., ACS Appl. Mater. Interfaces, 9, 37587-37596 (2017)

16) Ueno Y., et al., Cancer Biol. Ther., 12, 270-217 (2011)

17) Dimcevski G., et al., J. Control. Release., 243, 172-181 (2016)

18) ClinicalTrials.gov Identifier : NCT02343991

19) ClinicalTrials.gov Identifier : NCT02986932

20) Suzuki R., et al., Cancer Sci., 107, 217-223 (2016) 